\title{
The Sarrasani Circus in Opole. On Entertainment in the City in the First Decades of the $20^{\text {th }}$ Century ${ }^{1}$
}

\author{
Kamila Baraniecka-Olszewska \\ Institute of Archaeology and Ethnology, \\ Polish Academy of Sciences, Warsaw
}

\begin{abstract}
The article presents outcomes of the transformation of ethnographic shows into circus acts at the example of Sarrasani Circus performances in Opole (German: Oppeln) in the beginning of the $20^{\text {th }}$ century. The author examines how circus performances created experience of the extraordinary on stage by presenting faraway, distant, exotic cultures. Thus ethnographic shows in the Sarrasani Circus were an element of magic world of wonders performed at arena. The circus visited Opole thrice: in 1913, 1928 and 1933 becoming one of the main attractions in the city. Each time the shows were preceded by a huge advertising campaign in the local German- and Polish-language press. Press articles, notes and advertisements along with scarce archival data constitute the main source for the analysis, though they offer a very specific image of the past. Taking this into account, the author focuses on the manner of conceptualizing exotic cultures to make them attractive to the city audience. Such an approach enables research on the process of presenting exotic ethnic groups within a framework of city entertainment in the first decades of the $20^{\text {th }}$ century. Therefore what the author describes is a way in which distant cultures become a stage attraction, a circus trick and an element co-creating a fantastic reality on arena.
\end{abstract}

Keywords: circus, ethnographic shows, exotic cultures, Sarrasani, stage performance

1 The research that became the basis for the present article was financed by the National Science Centre, Poland 2015/19/B/HS3/02143. However, I would not have been able to complete it were it not for the help and support of the staff of the State Archives which I searched for materials. Naturally, in this case the assistance of the team at the State Archive in Opole was particularly valuable, yet I also owe a special debt of gratitude to Bogusław Małusecki, the head of the Gliwice department of the State Archive in Katowice. The manner in which he organized my work at the archive (and therefore the work of other people, whom I would also like to thank), as well as his exceptional kindness and the witty interest he expressed in the topic truly deserve to be called a model attitude in archival inquiry. He is also responsible for the fact that my file on circus performances in Silesia is full to the point of bursting. 


\section{INTRODUCTION}

The ethnographic shows of the latter half of the $19^{\text {th }}$ and early $20^{\text {th }}$ century have already become an established subject of academic study. The majority of scholars focus on shows staged in Western Europe and the United States, presenting performances by 'exotic peoples' in colonial context and noting how such entertainment facilitated the legitimization of power in the colonies and the consolidation of the academic theses of the time regarding the evolution of specific ethnic groups and the gradual development of civilization (ARNAUT 2011; BLANCHARD et al. 2008).

In time, such shows reached considerable popularity among $19^{\text {th }}$-century spectators. With every passing decade, however, their nature was shifting due to the ongoing changes, be it economic, social or political, as well as the nascent entertainment industry for the masses. The demand for such events made ethnographic shows go beyond their original colonial and academically ethnographic context, turning them into a product of mass culture associated with urban entertainment and the development of cities (DEMSKI 2018a). Having acquired a certain autonomy, they began to be staged outside of their countries of origin. From the late $19^{\text {th }}$ century onwards, German and American performance groups started to take their tours further east, to the regions currently labeled as Central-Eastern Europe. Ethnographic shows staged there have not yet been thoroughly studied. The subject requires a separate analysis which would not copy the interpretative solutions developed by scholars focusing on ethnographic shows in Western Europe and the United States, since existing studies suggest that in Central-Eastern Europe these performances acquired a different flavor, dependent on the local culture and political situation, while their reception did not always carry a strong connection to the colonial policies of European superpowers (BARANiecKa-OlszZewsKa 2020; CZARnecKa 2018, 2020; Demski 2018a, 2018b, 2020).

The present article contributes to the discussion on the differences between the ethnographic shows in Central-Eastern Europe and the ones staged in the Western world, focusing mainly on their interpretation as presented in the press. Local audiences frequently regarded performances of exotic peoples from the perspective of current political and social problems they found relevant (BARANIECKA-OLSZEWSKA 2020). The text also continues the analysis of ethnographic shows in present-day Polish territory (CZARnecka 2018, 2020; Demski 2018a, 2018b, 2020), and adds to the broad debate on the typology and internal diversity of stage shows performed by living members of exotic cultures. While some scholars perceive them as an aspect of the multifaceted phenomenon known as 'human zoos' (BLANCHARD et al. 2008; BLANCHARD et al. 2011), many others argue for the development of a separate classification for such performances (SÁNCHEZ-GómEZ 2013), in order to create independent methodologies for the phenomenon research (MADDRA 2006; SCARANGELla-MCNeLlY 2015).

The present study concentrates on circus performances as a form of ethnographic show (see CORBEY 2008). The history of such performances between the 1850s and the first decades of the $20^{\text {th }}$ century, reveal a certain evolution of the phenomenon, which shifted from displaying members of specific tribes on stage without any elaborate script, to showcasing their crafts and skills, and later to complex performances involving animals and stage sets imitating the natural environment of a given ethnic group (BLANCHARD et al. 2008). In time, stage performances of ethnographic groups began to be included in the repertoire of circus groups. 
As in the case of ethnographic shows organized in other circumstances, the exoticism of the ethnic groups performing in the circus was one of the aspects that drew the audiences in, and was therefore emphasized in posters, press notes and advertisements. It was not, however, the sole attraction. A successful circus performance also relied on the presentation of spectacular skills, and so different ethnic groups would show off their prowess at handling horses (cattle, elephants or camels), acrobatics, military techniques, shooting, equestrian vaulting, and sometimes martial arts. Ethnographic shows were therefore incorporated into the program of circus performances, alongside other displays of acrobatics, juggling and animal handling. They rarely dominated the shows and were not always present in the repertoire. Some circus troupes only focused on acrobatic performances or equestrian vaulting coupled with animal handling. In others, shows by ethnic groups were only included in the program for some seasons. The same circus could organize performances with or without ethnographic shows, depending on the program.

In the late $19^{\text {th }}$ and early $20^{\text {th }}$ century, Europe, including its Central-Eastern regions, was toured by many circus troupes. Some of them, such as the Barnum and Bailey Circus or Buffalo Bill's Wild West Show, hailed from the United States, others, like Angelo, Blumenfeld, Busch, Carré, Ciniselli, Hagenbeck, Henry, Kludsky, Maine, Strassburger, Sarrasani, and Victor, had been established in Europe. Aside from large circuses or entertainment companies, there were also smaller itinerant troupes, organizing shows of more modest proportions. Circus performances became one of the more popular forms of entertainment in European cities, be it big or small. Central-Eastern Europe was no exception, especially the regions reachable by railway, which greatly improved the mobility of circus troupes (see also DeMsKi 2018b).

Almost perfect conditions for such shows existed in Silesia, as its network of railway connections was particularly elaborate. Due to the rapid development of industry (mining, foundries) and agriculture in the region of Opole, railways spread across the entire countryside, reaching even the smaller towns. In the late $19^{\text {th }}$ and early $20^{\text {th }}$ century, the lands of Upper and Lower Silesia, currently within the borders of the Polish state, were under German administration. These territories, including the city of Opole (German: Oppeln) had not been a part of the Commonwealth of Poland and Lithuania before its partitions. ${ }^{2}$ During the period in question, Opole was a German city, even though it did have a Polish community and Polish-language press was published there at the beginning of the $20^{\text {th }}$ century.

In contrast to the nearby Wrocław ${ }^{3}$ (German: Breslau), the residents of Opole did not have many opportunities to see an ethnographic show. The tour routes designed by troupe impresarios passed through Wrocław and other cities, for instance Poznań (German: Posen) (see DEMSKI 2018b). It was not, however, the case with travelling circus troupes. Press materials and archives indicate that the number of circus performances organized in Opole was considerable, especially at the beginning of the $20^{\text {th }}$ century. Similarly to other cities in Silesia, Opole was visited by a sizable circus troupe at least once a year.

\footnotetext{
2 In 1772-1795, following concentrated political action by Prussia, Austria and Russia, the territory of the Commonwealth of Poland and Lithuania was divided between the three mentioned states. The Second Polish Republic - a sovereign state - reappeared on the map in 1918, after the World War I. Opole only found itself within Polish borders after the World War II.

3 On ethnographic shows in Wrocław see Czarnecka 2018.
} 
At the start of the $20^{\text {th }}$ century the population of Opole reached thirty thousand. It was a period of development for the city, which became industrialized around the mid$19^{\text {th }}$ century, owing to the establishment of several cement mills. The Great War brought crisis and halted Opole's growth. In 1922, however, the city became the capital of the Province of Upper Silesia and the seat of many institutions and offices. Development started anew, with the establishment of new communication routes, the construction of a new bridge and sport centers (PoBóG-LENARTOWICZ 2017). The rapidly changing city also had room for circus performances.

\section{THE CIRCUS IN THE 20 ${ }^{\text {TH }}$ CENTURY}

In the early $20^{\text {th }}$ century the circus was a popular form of urban entertainment (DANOwICZ 1984). Performing artists visited towns and cities, their arrival heralded by the emergence of circus tents surrounded by temporary quarters for the circus members. Urban space would then be filled with posters and program announcements. New train and tram connections were added to the schedule, to transport spectators to performances and take them home after the show ended. Very often the performances were preceded by a parade of artists and animals walking through the city. Thus, the presence of a travelling troupe affected not only the audience of the shows but had a degree of impact on other inhabitants as well.

As indicated by the numerous press announcements and the frequent reports of accidents that occurred during performances or in the course of circus careers, in the first decades of the $20^{\text {th }}$ century circus enjoyed immense popularity. It is all the more interesting given the fact that scholars saw these performances as a relic of the $19^{\text {th }}$ century: "the circus' association with the $19^{\text {th }}$ century is discernible from the artistic and aesthetic consistency developed at the time and preserved in the sequence of the same tricks (feats of equestrian vaulting, acrobatics, tightrope walking, juggling, and shows by clowns or wild animal tamers)" (BARCZ 2014:186). Nineteenth-century American circus performances organized by Phineas Taylor Barnum presented "fantastic beauty, a fairylike setting" that people from small towns and villages had never seen before (FLINT 1979:189). Such an idea for circus performances was transplanted to Europe, where it proved attractive to $20^{\text {th }}$-century inhabitants of cities and towns. The fact that ethnographic shows became an element of circus performance routines seems to be yet another proof of the circus' connections to $19^{\text {th }}$-century aesthetics and the contemporaneous understanding of the world, since "the evolution of the circus is directly related to European and American colonizers gaining advantage over the rest of the world. For this reason, the circus, in its origins, remains only one of the places created not solely for the purpose of entertainment, but to popularize the 'science' explaining the differences between human and animal races and the hierarchies existing in the world" (BARCZ 2014:188).

What, then, was the reason behind the popularity of such a dated form of entertainment? The beginning of the $20^{\text {th }}$ century did bring immense changes. The balance of power in Europe was rearranged. The transformations that took place in colonial superpowers after the Great War also had a profound impact on the world. Nevertheless, in the 1920s and 1930s circuses remained an immensely popular form of entertainment and continued to include ethnographic shows during which residents of European cities and 
towns could observe members of distant cultures and their extraordinary acrobatic or equestrian skills.

Although ethnic performances moved to circus tents, becoming an element of entertainment shows, their general context did not differ much from the circumstances of ethnographic spectacles of the past. They were still associated with taming the unknown, exotic reality. Circus shows were to create an extraordinary atmosphere, letting the audience step into a world of wonder, of exotic and mysterious cultures, teeming with tricks and magic. The feats of acrobatics, stage magic and animal taming made it seem as if the very laws of nature could be overturned. The extraordinary allure of the circus stems from crossing the limits of nature (SIEDLECKA 2017:321), which may be understood differently - from the physical skills of circus artists to emphasizing the already tame exoticism on stage.

'Such a manner of creating a need for seeing the 'inhuman,' stressing humankind's control over nature, crossing the limits of intimacy in relation to people from outside the realm of the white men, who were shown at exhibitions and in museums as living exhibits, was a part of the circus' history" (BARCZ 2014:188). During the late $19^{\text {th }}$ and early $20^{\text {th }}$ century the circus was still "a place one visited to "see the world" (CIHLÁr 2014:176). This attitude went hand in hand with the model of 'sensation fair' assumed by the circus groups of the day (CIHLÁr 2014:177), a model that lay at the very core of performance organization. It appears to also have been followed by the Sarrasani circus, since "in accordance with the Enlightenment ideal that one who was culturally superior had an obligation both to protect and to guide the savage, Sarrasani envisioned himself as a master of beasts and men, responsible and tempered in his exercise of authority" (Отте 1999:533, emphasis - M.O.).

\section{THE SARRASANI CIRCUS IN OPOLE}

The Sarrasani circus was founded in 1901 by Hans Stosch, a circus performer born in Łomnica (German: Lomnitz, Greater Poland), known under the stage name of Giovanni Sarrasani. It was an itinerant troupe visiting different cities in tours that could last for a number of years. Hans Stosch-Sarrasani managed to create a successful enterprise (DANOWICZ 1984:15). Despite its modest beginnings, by 1912 his circus became lucrative enough to merit the establishment of a permanent headquarters in Dresden, as other similar entertainment companies had done (Отте 1999). The building was destroyed by bombs in 1945 .

The Sarrasani circus was supposedly closer to American models (DANOwICz 1984:132), as its repertoire included not only tricks and feats of physical ability, but also presentation of distant cultures, staged as ethnographic exoticism. This aspect was also borrowed from other German tycoons of entertainment industry, such as the Hagenbeck family. The choices made by the circus founder were connected to the fascination with the indigenous inhabitants of North America (Ames 2008; Penny 2015). Germany may not have been the only European country to display interest in Indians, ${ }^{4}$ yet there the

4 The issue is mentioned by Christian Feest (2002); examples of regional interest in Indians may be found in Petra Kalshoven's book (2012) or Ildikó Sz. Kristóf's article (2017). 
trend resulted in an exceptionally elaborate academic discussion (FEEST 2002:38) and expressed itself in forms visible in the public sphere. These included participation in all sorts of Wild West shows, including the ones presented in the Sarrasani circus. Although its performers came from many different corners of the world, the circus was mainly famous for its Indian shows ${ }^{5}$ and... elephants (FIELDS 2012:456).

The Sarrasani circus visited Opole thrice: in September 1913 (four days of performances beginning on the $18^{\text {th }}$ ), in September 1928 (four days beginning on the $13^{\text {th }}$ ) and in August 1933 (four days again, beginning on the $10^{\text {th }}$ ). Each time the shows were preceded by an advertising campaign in the press - very elaborate in the Germanlanguage publications and only slightly more modest in the Polish-language ones. The visits were a part of a larger tour around Silesia.

\section{3}

The circus arrived in Opole with some delay, having extended its schedule of performances in Wrocław owing to the great interest they sparked in the public. The visit was widely advertised in the press. A little over a week prior to the performances, the Oppelner Zeitung started to publish articles on the circus' history, reports on the troupe's journey to Opole, as well as notifications summarizing the performance program and describing the visit as an extraordinary event. The authors emphasized the warm reception the show had received in other cities in Europe, such as Berlin, Vienna, Brussels, Frankfurt and Dresden, as well as Wrocław. The advertisement in Nowiny (1913 no 108)6 promised the audience the following:

"Sarrasani's World Show. Sarrasani is a metropolitan enterprise. Sarrasani soars above mediocrity in anything and everything. Sarrasani presents nothing but delight. Sarrasani is appreciated in its homeland as well as abroad. Statistics demonstrate that Sarrasani is incomparable. Official records testify to the educational, artistic and athletic value of the spectacle. Schoolteachers bring the youth to see the enterprise.

Sarrasani's elephants. The largest, best-trained and most expensive group of elephants in the world! These enormous colossi will amaze you with the strangeness of their motions. The group of 16 Indian giants is imposing and frightening indeed.

Sarrasani's Siberian tigers are the first trained beasts of their kind. No-one had attempted to tame these before. Sarrasani had brought the first mass transport of Siberian tigers to Europe. Siberian tigers surpass the Bengal tigers seen to this day in Germany, twofold or even threefold in terms of size, and even more in terms of cunning and savagery.

\footnotetext{
5 Fully aware of how problematic it is to use the collective term 'Indians' in reference to the native population of North America, I nevertheless choose to do so, as the denomination is now associated with certain imagery, stereotypes and manners of presentation of the indigenous cultures of North America, described in academic literature and relevant in the context of the present article.

6 The same announcement appeared in German in the Oppelner Zeitung, 1913 no 212.
} 
Sarrasani's Bengal lions are the very pinnacle of trained beasts and constitute the largest group of Berber tigers, never before brought to Europe in its entirety. The elegance of the tamer is juxtaposed against the majesty of the howling, roaring wild creatures that can barely be restrained with gunshots.

Sarrasani's camels. An entire caravan of Persian and African pedigree camels of all breeds. The first and only camels in the world trained in groups with no restraints whatsoever. A sight of exotic splendor. An unmatched spectacle by Sarrasani.

Sarrasani's sea lions. The clowns of the animal kingdom, these beasts truly are a wonder of nature. The sea lions, of which Sarrasani has the largest and best-trained regiments, are artists of unparalleled skill. Their ambition and dexterity is hilarious indeed.

Sarrasani's exotic animal spectacle makes up an admirable and educational part of the great show. The most bizarre animals are seen in numbers: Transvaal zebras, hippopotamuses, kangaroos, tapirs, chimpanzees, Indian buffalo, packs of dogs and various monkeys.

Sarrasani's horses. No other enterprise in the world possesses an equally valuable and diverse stables. Sarrasani holds the world record with his 200 noble steeds. The training of the animals is thoroughly classic.

Sarrasani's artists are a team of the best performers of all countries and nationalities in Europe and the United States of North America. Sarrasani presents the bravest trapeze artists, graceful acrobats, the most dignified riders, stunning equestrian vaulters, the most experienced tamers, and last but not least the most hilarious, peerless jesters and clowns.

Sarrasani's Arabs are the most daring and deadly courageous in jumping. Beautiful, imposing and proud figures one and all, they appear in caravans and bring about charming visions of the Eastern country.

Sarrasani's Japanese are the only court artists of Japan that have ever visited Europe and are allowed to perform solely at Sarrasani's. Their costumes sprinkled with gold are gifts from the late Mikado.

Sarrasani's Chinese possess the secrets of ancient magic, which no European may ever dare to comprehend. Agents of the wondrous country of unfathomable and undiscovered beauty.

Sarrasani's Indyans (sic!). The first real Indyans that ever travelled to the German interior. After long diplomatic talks with the American government, and for a hefty bail, these romantic personages, the last of their tribe, were successfully recruited by Sarrasani.

Sarrasani's Cowboys are the most audacious and temperamental riders, the bravest heroes of wild equestrian games, unmatched in throwing lassos, torches or hatchets, as well as in handling a gun. 
Sarrasani's musical orchestra comprises an ensemble of Cowboys, an ensemble of Turks, a Hungarian band, a brass orchestra of German cavalrymen, and a Bersaglieri corps. International music."

The advertisement promised a remarkable spectacle: an elaborate show of exoticism composed of tricks featuring wild animals and performances presented by members of foreign cultures demonstrating their abilities.

One of the numbers of Nowiny, a Polish-language newspaper published in Opole (1913 no 110) was supplemented with a special appendix entitled Przeglad Światowy. Sarrasaniego Gazeta Ilustrowana [World Review. Sarrasani's Illustrated Paper], containing information on the circus, its history and the attractions it offered. The appendix stated that the show would be hosted not in Opole, but in Opava (German: Troppau), a mistake promptly noted by local journalists. ${ }^{7}$ Interestingly, press advertising praising the extraordinary nature and grandeur of the spectacle also emphasized the technical equipment the circus had at its disposal:

\begin{abstract}
"Even the exterior of Sarrasani is a technological wonder. The entire company is transported by two large trains. It has more than 100 private carriages serving as offices, residential space and storage. Transport from the railway station to the site of the performance is facilitated by 10 street locomotives, a novelty in the Sarrasani circus. Forty circus tents make up a picturesque city, the gate of which is adorned with a majestic façade. The city of tents contains what follows: the greatest tents ever built in Europe, machine rooms, menageries, sties, living quarters for around 200 persons, colonies of Indian wigwams, kitchens, a unit of fire police, administrative offices, electricity control room and a first-class restaurant."
\end{abstract}

Thus, Sarrasani made the impression of a modern circus keeping in touch with the progress of technology, not only introducing novelties to its program, but also offering the latest solutions (see OTтE 1999:534).

As reported by Nowiny (1913 no 113:2), the shows in Opole were to feature a performance by Sioux Indians. Native Americans were scheduled to appear alongside members of other cultures, such as the Chinese, the Japanese and Arabs, yet the Wild West Show was advertised and described separately. This points to a continuous and unwavering interest in Indian culture (Отте 1999). The Oppelner Zeitung (1913 no 208) informed that the Wild West show performers would include eighty real Indians and cowboys. As emphasized by the press, they were the first actual Indians to visit Europe after the American government limited the native population's right to travel. Moreover, the press note suggests that the process of bringing them to Europe had been difficult and was completed successfully only due to Hans Stosch-Sarrasani's close acquaintance with Miller. ${ }^{9}$

It appears that the emphasis on the presence of Indians in the circus arena was in keeping with the vision of the circus director. As Marline Otte puts it: "Sarrasani saw himself as an explorer and a creator of foreign worlds: he was fascinated not only by what

\footnotetext{
7 Nowiny, 1913 no 110.

8 Nowiny, 1913 no 105.

9 Oppelner Zeitung, 1913 no 213. On the role of The Miller's Brothers' 101 Ranch Real Wild West in recruiting indigenous people for shows in Europe see FIELDS 2012.
} 
these Native Americans were, but what he could make them be" (1999:535, emphasis M.O.). He used the presence of Indians to create a truly exotic stage show, designed by him and largely consistent with European stereotypes regarding native Americans. Steps aimed at making their presence on stage more dramatic were taken since the moment the Indians were recruited.

\footnotetext{
"When these performers were initially hired in the United States or Canada, they were asked to provide feathers (Federschmuck), bows and arrows, pipes, and tents. Sarrasani also quickly replaced their real names (Brown or Smith) with the more exotic White Eagle, Big Snake, or Black Horse. A 'chief' was quickly appointed, and faux tribal structures were officially established. Women were asked to embroider moccasins with shells and glass-pearls, and men were instructed to strike picturesque and noble poses" (Отте 1999:536).
}

In Europe and in the United States, Wild West performances featuring native Americans reflected the stereotypical image of Indians and reproduced it on stage. Such methods of dramatizing stage personas of Indians were introduced at Millers Brother's 101 Ranch, from where native Americans were recruited for Sarrasani's shows (FIELDS 2012:447). They debuted in the circus show in 1913 and participated in the tour around Silesia.

It is unclear whether the audience enjoyed the Sarrasani performances, and whether the Indians, so advertised in the press releases, did attract the spectators' attention. Interestingly, no reviews of the show may be found in the local papers, even though they did print the circus troupe's advertising materials. Sarrasani's visit in Opole was only mentioned in two notes. One reports that the funds gathered at a charity event were stolen during the parade of circus artists and animals ${ }^{10}$ (announced in the Oppelner Zeitung, 1913 no 216). The other contains the information that two 'Negroes' [original term] from the circus attended Sunday mass and took communion. ${ }^{11}$

\section{8}

The next visit of the Sarrasani circus in Opole happened 15 years later, on September the $13^{\text {th }}$. As before, its arrival was delayed by four days due to the show's success in another city (this time it was Bytom, German: Beuthen). Since its last stay in Opole, the circus had managed to recover after the crisis of the Great War, make its first journey across the ocean to South America and begin a new tour which also encompassed cities in Silesia. The promotional material printed in the press informed that, having attended an international conference on tourism organized in Hamburg, Sarrasani was visiting Silesia in order to try out new attractions that could appeal to 'trip makers'. ${ }^{12}$

\footnotetext{
Nowiny, 1913 no 111.

11 Nowiny, 1913 no 112.

12 Katolik Codzienny, 1928 no 156; Nowiny Codzienne, 1928 no 152.
} 
As before, the press advertisements promised an event to remember:

"The magnificent company is therefore to perform for four days in Opole. On Monday next, that is the $10^{\text {th }}$, lorry cars shall be transporting 26 lions, 14 tigers, sea lions, leopards, one sea horse, subtropical bears, etc., furthermore, there will be special trains carrying 22 Indian elephants, 200 horses, herds of camels, zebras and buffalo. All of it: shall reach Opole on Monday. An entire host of exotic peoples will arrive in Opole: the Chinese, the Japanese, the Hindus, Arabs, Mulattos, Negroes, Circassians, Georgians, real Indians with their chief 'White Buffalo'. Sarrasani's city of tents will be illuminated in the evening by 15000 electric lamps. 100 artists will make music."13

Information regarding circus flooded the local press for several months before the troupe's arrival, lauding the event as the highest form of entertainment, the pinnacle of technological progress offered at a 'peacetime' price. The performance was said to present a vast variety of cultures from which the artists hailed:

\begin{abstract}
"In its impressive arena - the largest in existence - one can see artists from 37 countries from all corners of the world. It is there that the daring riders of the Russian steppe dash about, along with bronze-skinned fakirs and Hindu dancers, along the black children of Africa, along lithe Chinese and Japanese people, along Mongolian spear warriors. South America provided Sarrasani with its proud hot-blooded residents from the Pampas of Argentina and sun-swept Brazil, the dark-skinned Mulattos and Creoles; Riffians sashay across the stage, while the sovereign chief of the Indians, 'White Buffalo', who had been received with pomp and honor by the magistrate of Berlin, brings his red-skinned warriors up onto the stage. Sarrasani assembles 500 people from all over the country in his 'Most beautiful spectacle of two worlds'."14
\end{abstract}

As before, the performance by native Americans served as the cornerstone of the spectacle. "Sarrasani's show culminates with the 'Wild-West' scene with real Indians, including their chief 'White Buffalo', cowboys, cowgirls, bareback riders, a magnificent Indian ballet." ${ }^{\prime 5}$ The entire advertising campaign was centered around the organization of this performance. Problems with bringing Indians to Europe were reported in the press. Sarrasani introduced himself as the sole circus proprietor who managed to overcome this obstacle, since the government of the United States was allegedly reluctant to allow native Americans to work in European circus troupes and made it difficult for circus owners to enliven their shows in such a manner. As presented in the press, Sarrasani's success was due to his close friendship with the Indians, especially one of their chiefs, White Buffalo, who made the employment of Indians in the circus possible:

"White Buffalo owns large swaths of land and a farm equipped in an entirely modern fashion, and holds authority over circa 1200 tribesmen. He had immediately decided to go with Sarrasani along with his people. Yet even this Indian encountered unforeseen obstacles, put before him in the emigration office in Washington. These obstacles were, however, overcome by the brave Indian himself. He declared that should he not receive the permission to travel to Europe, he

13 Nowiny Codzienne, 1928 no 208.

14 Nowiny Codzienne, 1928 no 164.

15 Nowiny Codzienne, 1928 no 198. 
would proceed to sell all his property and drink all the profits away. The statement proved effective. White Buffalo was allowed to leave for Europe with his warriors, medics, dancers, women and children. Thus, Sarrasani came into possession of his Indians, whom he directs to perform during all his shows, in a pantomime presenting the wild west."16

There was, however, some confusion surrounding the performance. The press warned its readers to be wary of scammers trying to extort goods from merchants by saying they work at the circus and offering a free entry ticket in exchange. ${ }^{17}$ Moreover, there appeared a rumor that the tickets for all performances had already been sold out. Consequently, potential spectators did not express any interest in the circus, which caused Sarrasani to lose a substantial amount of money. The Nowiny Codzienne (1928 no 208) reported that he was looking for the culprits behind this misunderstanding. ${ }^{18}$

Ultimately, however, the performances in Opole proceeded as planned. The Nowiny Codzienne (1928 no 214) printed a short review of the first show, evidently commissioned by the circus. It provided some information on the organization of the circus town of tents and wagons, which sparked almost as much interest as the shows themselves. It appears to have been designed to be an attraction in itself, as it was divided into 'districts' that could draw the audience's attention. The review mentions, for instance, that in the Indian district "one can see a number of tents, which the Indians call wigwam. Ladies, curious as always, peek inside of these through discretion slits, just to see the curious stares of Indian maidens". The description of the show also clearly indicates that the audience's attention was being directed towards the Native Americans. "The scene from the wild west, acted out by Indians and cowboys locked in combat, was very interesting indeed. Riders dashed across the arena with dazzling speed. The hidden enemies caught them with a lasso, that is with a hooped cord that can be thrown onto an opponent. The victim, so entangled, drops down and falls into the hands of the ambusher."

Interestingly, promotional materials for the performances may be found not only in the press. The collection of documents at the State Archive in Opole pertaining to the 1928 visit of the Sarrasani Circus in that city mainly contains copies of notes written to director Hans Stosch-Sarrasani by other municipal authorities (e.g. from Głogów [German: Glogau], Legnica [German: Liegnitz], Zielona Góra [German: Grünberg in Schlesien], Gorzów Wielkopolski [German: Landsberg-Warthe], Szczecin [German: Stettin], Bernburg, Hannover, Chemnitz, and also Frankfurt an der Oder, and Magdeburg), expressing gratitude for organizing such a splendid program of performances and contributing to the development of the given city. ${ }^{19}$ The administration of Opole received more than ten copies of such documents. ${ }^{20}$ Naturally, none of these expressed any negative opinions on the enterprise. It is therefore apparent that the advertising campaign of the circus targeted not only potential spectators, but the local authorities as well. With

\footnotetext{
Nowiny Codzienne, 1928 no 186.

Nowiny Codzienne, 1928 no 205; Oppelner Zeitung, 1928 no 207.

8 See also Oppelner Zeitung, 1928 no 207.

19 Opole, Archiwum Państwowe [State Archive], 45/22/0/6/2528: Gastspiel Zirkus Sarrasani 1928-1933.

20 The remaining documents in the collection are letters pertaining mainly to the organization of transport to the arena site, permission for advertising the shows in the city and extending the curfew. It also contains Sarrasani's schedule for later in the year.
} 
the former group, the advertising focused on the attractiveness of Sarrasani's program, with the latter - on the performances' impact on the welfare of the location in which they were staged. However, neither the press, not the archives reveal any information on the reception of the show or the reactions of the audience.

\section{3}

The third and final round of performances organized in Opole by the Sarasani circus took place in 1933. Once again, the German state had changed significantly since their previous visit. Adolf Hitler had already come into power and the persecution of Jews gained momentum. The ideas of German nationalism had seeped their way into circus and entertainment companies (Отте 1999:541). The director of the Sarrasani circus may not have been unilaterally supportive of Hitler's policies, as evidenced by the following episode in the Silesian tour the circus made in 1933. The paper Górnoślazak (1933 no 171) reported that a fire broke out in Sarrasani's representative train transporting artists, as it travelled from Racibórz (German: Rattibor) to Gliwice (German: Gleiwitz) after nightfall. Although the cause of the incident remained unclear, it was stated that "in the leftist circles there prevails the opinion that the perpetrators were Hitlerist storm troopers wishing to retaliate for the fact that the numerous flags adorning the representative carriage included Polish and French colors".

Sarrasani's true opinion on the government of the Third Reich is, however, difficult to ascertain. The State Archive in Opole is in possession of a letter sent from the circus administration office to the city's magistrate, informing of an article on the Sarrasani Circus entitled Allen Gewalten zum Trotz sich erhalten ${ }^{21} \ldots$ Sarrasani ein Deutscher Begriff (To keep yourself in spite of all forces... Sarrasani the Idea of Germanness), printed to celebrate the Chancellor's birthday. A copy of the text was even appended..$^{22}$ It traced Hans Stosch-Sarrasani's family line back to the $16^{\text {th }}$ century. The lives of his ancestors were inextricably entwined with the history of Germany, presenting Sarrasani as someone with a deep connection to the fate of his country. His circus productions, in turn, were portrayed as perfectly appealing to the tastes of the German society in the wake of the changes to come. The text was sent to incite the local authorities to grant their permission to another round of circus performances in the city. It appears, therefore, that Sarrasani did not, or could not, strive to cut himself entirely off the world of politics. On the contrary, as Otte notes: "although Sarrasani did not want to position himself in any political camp, he had a strong instinct for what was politically opportune" (1999:541). His willingness to use a press article overly compliant with Germany's current policy line may have been an example of employing this instinct. It is unclear whether the

${ }_{21}$ It is a passage from Johann Wolfgang von Goethe's poem Feiger Gedanken...: "Allen Gewalten/ zum Trutz sich erhalten". The same verses were written by Hans Scholl on the wall of the cell in which he awaited his sentence.

22 Opole, Archiwum Państwowe, 45/22/0/6/2528: Gastspiel Zirkus Sarrasni 1928-1933, a letter to Opole municipal office: An Den Magistrat Oppeln, April 23, 1933, pages unnumbered. I was not able to determine the title of the paper in which it appeared; it was most likely one of the periodicals published in Dresden. 
article had any influence on the authorities' decision, yet ultimately Hans Stosch was allowed to perform in Opole once more. As the Oppelner Zeitung reported, before the opening show, throngs of visitors flooded to the city (1933 no 184).

Even though the circus' visit was noted in all the papers in the region, the advertising campaign seems to have been less extensive than before. Only two mentions of the circus performance may be found in the Nowiny Codzienne. Naturally, the notes promised unforgettable experiences, opulent and luxurious. This time, however, the program was arranged in a slightly different fashion.

\footnotetext{
"This year's performances feature exquisite decorations and feats of unrivalled skill by real Chinese tumblers. The innovation is connected to the second expedition to South America, which Sarrasani's circus intends to undertake in a short while. Since colored folk does not count as any rarity in America, Sarrasani wishes to awe his audience with the program, the very same one he will present in Opole. With this program, director Stosch-Sarrasani proves once again that his circus takes the first place in the whole world." 23
}

The note also contains the following statement: "It is my intention to snatch people away from their mundane existence and transport them to a fairytale land of sparkling wonder". This magical world was still centered around the exoticism of foreign cultures and their alienness to European eyes. "To all those who cannot set out to travel to faraway, beautiful paces, I wish to present an image of the art of these peoples and the unknown secrets of the animal kingdom of those parts which had captivated our imagination in our younger years and fed it with all sorts of dreams". ${ }^{24}$ Like all the preceding ones, the 1933 program was advertised as a new development, differing from any circus performances thitherto seen in the world. This time, however, Sarrasani forsook the Wild West shows, with which he came to be associated, in favor of a presentation of Asian cultures. Aside from the wild animals, it was the Chinese troupe and its performance that was to serve as the main attraction. The 1933 performances marked the last visit of the circus not only in Opole, but in the entire Silesia as well.

The years that followed proved very turbulent for the Sarrasani company. Its founder, Hans Stosch-Sarrasani Senior, died in 1934 in Brazil, during the troupe's tour across South America. Hans Stosch-Sarrasani Junior brought the circus back to Europe in 1936 and served as its director until his death in 1941. Since then the company was in the hands of his widow, Trude Stosch-Sarrasani. The circus continued to operate throughout the war, although its new director was briefly detained in 1944 for anti-German behavior. In 1948 she emigrated with the Sarrasani circus to Buenos Aires in Argentina. ${ }^{25}$

\footnotetext{
Nowiny Codzienne, 1933 no 170.

Nowiny Codzienne, 1933 no 170.

25 Under Trude Stosch-Sarrasani's management, the circus in Argentina operated until 1972. Her branch of the company was the direct continuation of the Sarrasani circus founded by Hans Stosch. However, one of Sarrasani's former associates, Fritz Mey, established a new Sarrasani Circus in Germany in 1956. This enterprise closed in the year 2000.
} 


\section{CONCLUSION}

In the $20^{\text {th }}$ century, the nature of ethnographic shows underwent significant changes. The circus gave them a new life and allowed them to retain their popularity; although their appeal still remained in the visual presentation of exoticism, this in itself was no longer the objective. Members of foreign cultures were presented on stage mainly as a means for developing an artistically interesting program. Ethnic shows contributed to the creation of a fantastic, extraordinary stage reality. This was the role they played in the Sarrasani Circus: "unlike museum curators or scientists who emphasized either the scientific value of ethnographic displays or their importance for the colonial cause, Sarrasani was concerned with their theatrical value above all else" (Отте 1999:535). Interestingly, the director himself was involved in creating an air of wonder and mystery through references to the exoticism of faraway cultures, appearing on stage dressed as a Maharajah, frequently riding on an elephant's back (Отте 1999:534).

The lack of data makes it difficult to ascertain how exactly this theatrical value was achieved, how the stage reality was constructed and what was the relation between the popular image of exotic cultures and the manner in which they were presented on stage. Currently available sources are mostly limited to press materials, which offer a very specific image of the past. It is all the more pronounced given the fact that the vast majority of these texts are advertisements or promotional articles, which in themselves present certain visions and projections, in this case pertaining to the circus and its role in urban entertainment. At the same time, however, such texts formed a certain interpretative framework for the events they advertised. Although spectators of circus shows were not uncritical towards such press releases, the analysis of promotional material makes it possible to reconstruct the language used to describe the extraordinary, unusual and sensational nature of distant cultures and the role the entertainment industry assigned to them throughout the decades.

Thus, the study of Sarrasani's performances in Opole must, by default, be focused on the advertising campaign for the event, and therefore on the manner of conceptualizing exotic cultures to make them attractive to the audience. The interpretation of circus performances may not lead to understanding how inhabitants of a Silesian city interacted with members of geographically distant cultures or how they conceptualized the presence of such people in Europe, but nonetheless provides information on the process of isolating ethnic groups within the framework of stage entertainment. What may be observed is a specific type of operationalization: distant cultures become the advertised stage attraction, a circus trick, an element of a supernatural, fantastic world performed on stage.

\section{REFERENCES CITED}

Ames, Eric

2008 Seeing the Imaginary: On the Popular Reception of Wild West Shows in Germany, 1885-1910. In Blanchard, Pascal - Bancel, Nicolas - Bö̈TSCH, Gilles - Deroo, Éric - Lemaire, Sandrine - Forsdick, Charles (eds.) Human Zoos. Science and Spectacle in the Age of Colonial Empires, 205-219. Liverpool: Liverpool University Press. 
ARNAUT, Karel

2011 The Human Zoo as (Bad) Intercultural Performance. In BLANCHARD, Pascal Bö̈tsch, Gilles - JacomiJn Snoep, Nanette (eds.) Human Zoos: The Invention of the Savage, 344-360. Arles: Actes Sud and Paris: Musée du Quai Branly.

BARANiECKA-OlszewsKa, Kamila

2020 Buffalo Bill and patriotism. The Criticism of the Wild West Shows in Polish BARCZ, Anna. press in 1906. East Central Europe (in print).

2014 Zmierzch cyrku w 'Zwierzyńcu' Antoniego Ferdynanda Ossendowskiego na tle rozkwitu kultury cyrkowej w XIX wieku [The Twilight of Circus in 'Zwierzyniec' by Antoni Ferdynand Ossendowski in the Context of the Development of the Circus Art in the $19^{\text {th }}$ Century]. Napis 20:184-198.

Blanchard, Pascal - Bancel, Nicolas - Bö̈tsch, Gilles - Deroo, Eric - Lemaire, Sandrine - ForSDICK, Charles (eds.)

2008 Human zoos. Science and Spectacle in the Age of Colonial Empires. Liverpool: Liverpool University Press.

Blanchard, Pascal - Boëtsch, Gilles - Jacomisn Snoep, Nanette (eds.)

2011 Human Zoos: The Invention of the Savage. Arles: Actes Sud and Paris: Musée du Quai Branly.

Cinlář́, Ondř̀j

2017 Od cyrku tradycyjnego do współczesnego [From the Traditional to the Contemporary Circus]. In Kondrasiuk, Grzegorz (ed.) Cyrk w świecie widowisk, 169-208. Lublin: Warsztaty Kultury w Lublinie.

CORBEY, Raymond

1993 Ethnographic Showcases, 1870-1930. Cultural Anthropology 8(3):338-369.

CzARNECKA, Dominika

2018 'A w niedzielę szło się oglądać ludzi.’ Pokazy etnograficzne we wrocławskim ogrodzie zoologicznym 1876-1930 ['And on Sunday We Went to Watch the People'. Ethnographic Shows in the Wrocław Zoological Garden between 1876 and 1930]. Etnografia Polska 62(1-2):183-198.

2020 'Black' Female Bodies and the 'White' View. The Dahomey Amazon Show in Poland at the End of the Nineteenth Century. East Central Europe (in print).

DANOWICZ, Bogdan

1984 Byt Cyrk Olimpijski... [There Was the Olympic Circus...].Warszawa: Iskry.

Demski, Dagnosław

2018a Azja w cudzych oczach. 'Pokazy' ludów azjatyckich na ziemiach polskich na przełomie XIX i XX wieku [Asia in Foreign Eyes. Ethnographic Shows of Asian Peoples on Polish Lands in the Turn of the $20^{\text {th }}$ Century]. In BARANIECKAOlszewska, Kamila - KabZIŃSKA, Iwona - TANGAD, Oyungerel (eds.) Lokalne $i$ globalne perspektywy azjanistyczne. Księga jubileuszowa dla Profesora Sławoja Szynkiewicza, 295-308. Warszawa: Wydawnictwo IAE PAN.

2018b 'Spoglądając wstecz'. Wystawa szczepów z Doliny Nilu w Poznaniu, 1914 ['Looking Back'. Poznań Exhibition of the Tribes of the Nile Valley, 1914]. Etnografia Polska 62(1-2):199-219.

2020 Spaces of Modernity. Exotic Shows in Poznań, 1879-1928. East Central Europe (in print). 
FeEsT, Christian F.

2002 Germany's Indians in a European Perspective. In Calloway, Colin G. Gemünden, Gerd - Zantop, Susanne (eds.) Germans and Indians: Fantasies, Encounters, Projections, 25-43. Lincoln: University of Nebraska Press.

FIELDS, Alison

2012 Circuits of Spectacle: The Miller Brothers' 101 Ranch Real Wild West. American Indian Quarterly 36(4):443-464.

FLINT, Richard W.

1979 The Evolution of the Circus in Nineteenth-Century America. In MatLaw, Myron (ed.) American Popular Entertainment: Papers and Proceedings of the Conference on the History of American Popular Entertainment, 187-195. Wesport (CT)-London: Greenwood Press.

Kalshoven, Petra T.

2012 Crafting the Indian. Knowledge, Desire \& Play in Indianist Reenactment. New York-Oxford: Berghahn Books.

MADDRA, Sam

2006 Hostiles? The Lakota Ghost Dance and Buffalo Bill's Wild West. Norman: University of Oklahoma Press.

2008 American Indians in Buffalo Bill's Wild West. In Blanchard, Pascal Bancel, Nicolas - Bö̈tsch, Gilles - Deroo, Éric - Lemaire, Sandrine ForsDick, Charles (eds.) Human Zoos. Science and Spectacle in the Age of Colonial Empires, 134-141. Liverpool: Liverpool University Press.

Oтте, Marline

1999 Sarrasani's Theatre of the World: Monumental Circus Entertainment in Dresden, from Kaiserreich to Third Reich. German History 17(4):527-542.

Penny H., Glenn

2015 Kindred by Choice: Germans and American Indians since 1800, US: University of North Carolina Press.

Pobóg-Lenartowicz, Anna

2017 Od opola do Opola. Popularna historia miasta [From Opole (as an administrative term) to Opole (as a city name). Popular history of the City]. Opole: Nowik.

SÁNCHEZ-GómEZ, Luis A.

2013 Human Zoos or Ethnic Shows? Essence and Contingency in Living Ethnological Exhibitions. Culture \& History Digital Journal 2(2):1-25.

SCARAngella MCNenly, Linda

2015 Native Performers in Wild West Shows. From Buffalo Bill to Euro Disney. Norman: University of Oklahoma Press.

SiedleCKa, Sylwia

2017 Wokół pojęcia cyrku [Around the Term 'Circus']. In KonDRASIUK, Grzegorz (ed.) Cyrk $w$ świecie widowisk, 313-330. Lublin: Warsztaty Kultury w Lublinie.

Sz. KRISTóF, Ildikó

2017 (Multi-)Mediatized Indians in Socialist Hungary: Winnetou, Tokei-ihto and Other Popular Heroes of the 1970s in East-Central Europe. In Demski, Dagnosław - Kassabova, Anelia - Sz. Kristóf, Ildikó - LaINeSTE, Liisi - 
Baraniecka-Olszewska, Kamila (eds.) The Multi-mediatized Other. The Construction of Reality in East-Central Europe, 1945-1980, 128-155. Budapest: L'Harmattan.

THODE-ARORA, Hilke

1989 Für fünfzig Pfennig um die Welt. Die Hagenbeckschen Völkerschauen [For Fifty Pfennigs around the World. Hagenbeck's Ethnographic Shows]. Campus Verlag, Frankfurt-New York.

\section{ARCHIVAL SOURCES}

Opole

Archiwum Państwowe [State Archive], collection no. 45/22/0/6/2528: Gastspiel Zirkus Sarrasani 1928-1933.

Kamila Baraniecka-Olszewska, Ph.D., studied ethnology and Latin American studies. Since 2007 she has worked in the Institute of Archaeology and Ethnology of the Polish Academy of Sciences in Warsaw. Her main field of interest has been anthropology of religion and performance studies with particular emphasis put on forms of religious expression. She received her Ph.D. from Warsaw University in 2011 on the basis of thesis devoted to Passion plays in contemporary Poland. Recently she has finished a project on historical reenactments in Poland. She is an author of over twenty articles dealing with contemporary religiosity and with perceiving and representing history. She also wrote a book on Passion plays The Crucified. Contemporary Passion Plays in Poland (de Gruyter 2017) and a book in Polish about historical reenactments of World War II: Rekorekonesans: praktyka autentyczności. Antropologiczne studium odtwórstwa drugiej wojny światowej $w$ Polsce [Reenactment reconnaissance: the practice of authenticity. An anthropological study of World War II historical reenactment in Poland], (Kęty: Wydawnictwo Derewiecki 2018). ORCID ID: https://orcid.org/0000-0002-9560-3167 E-mail: kamila.baraniecka@gmail.com 